\title{
Isozyme Variation in Indian and Chinese Melon (Cucumis melo L.) Germplasm Collections
}

\author{
James D. McCreight ${ }^{1}$ \\ U.S. Department of Agriculture, Agricultural Research Service, U.S. Agricultural Research Station, \\ 1636 E. Alisal Street, Salinas, CA 93905 \\ Jack E. Staub, Anabel López-Sesé, and Sang-Min Chung \\ Vegetable Crops Research Unit, U.S. Department of Agriculture, Agricultural Research Service, \\ Horticulture Department, University of Wisconsin, Madison, WI 53706
}

\begin{abstract}
ADDITIONAL INDEX WORDS. allozymes, genetic markers, genetic diversity, germplasm management
ABSTRACT. Genetic variation among 378 melon (Cucumis melo L.) germplasm accessions collected in India in 1992 and 26 accessions in China in 1994 was evaluated with 19 isozyme loci. 'Top Mark' and 'Green Flesh Honeydew', which represented two distinct $C$. melo ssp. melo L. groups, Cantalupensis and Inodorus, respectively, were used as reference cultivars. Genetic distances among accessions were calculated, and an initial cluster analysis using these distances resulted in 148 groups of varying size, ranging from two to 47 accessions. One accession from each of the 148 groups was chosen at random and used in a second cluster analysis that identified 11 accession groups. Group 1 was unique and consisted of only two $C$. melo ssp. agrestis (Naudin) Pangalo accessions. Two large branches were detected at cluster node 2. One branch was comprised of three groups of 3,12 , and 34 accessions, while the other branch contained seven groups of 2, 3, 14, 16, and 47 accessions, and the reference cultivars. Of the 148 accessions, 132 were from 41 sites in Rajasthan and Madhya Pradesh, India, which were distributed unequally across the 11 groups. The 14 Chinese accessions originating from seven provinces were also dispersed unequally in the four major cluster groups. 'Top Mark' and 'Green Flesh Honeydew' were genetically distinct and uniquely clustered in the same group. These results indicate that additional collections of melon germplasm should be made in eastern and southern India.
\end{abstract}

Cucumis melo is a morphologically diverse crop species consisting of two subspecies that are differentiated on the basis of ovary pubescence (Kirkbride Jr., 1993), C. melo ssp. agrestis and $C$. melo ssp. melo. Six subspecific groups of cultivated and wild types have long been recognized in the western literature (Robinson and Decker-Walters, 1997). A more recent treatment of melon taxonomy by Pitrat et al. (2000) using literature and analysis of melon germplasm available to western taxonomists and newly available germplasm from the former Soviet Union resulted in the provisional, albeit testable, classification of melon into 16 groups, five in subspecies agrestis and 11 in subspecies melo. Upon more rigorous analysis, these groups might be more accurately defined as "cultivar-groups" according to Spooner et al. (2003).

Melon is a tropical, old world species that probably originated in Africa (Kerje and Grum, 2000). Afghanistan, China, India, Iran, Saudi Arabia, southern Russia, and Turkey were important secondary gene centers that gave rise to cultivated melons (Jeffrey, 1980; Pangalo, 1930; Whitaker and Bemis, 1976; Whitaker and Davis, 1962). The primary center for diversity in melon is southwestern and central Asia, mainly Turkey, Syria, Iran, Afghanistan, north and central India and Transcaucasia, Turkmenistan, Tadjikistan, and Uzbekistan (Esquinas-Alcazar and Gulick, 1983). Secondary centers of diversity for cultivated melons are found in China, Korea, Portugal, and Spain (Esquinas-Alcazar and Gulick, 1983). Today, melons are grown in many countries worldwide for local, national, and export markets (Robinson and Decker-Walters,

Received for publication 17 Dec. 2003. Accepted for publication 13 Mar. 2004. Mention of a trade name, proprietary product, or specific equipment does not constitute a guarantee or warranty by the USDA and does not imply its approval to the exclusion of other products that may be suitable.

${ }^{1}$ To whom reprint requests should be addressed.
1997). The fruit may be eaten fresh when immature as a vegetable, or mature as sweet, delicately flavored dessert fruit, or they may be processed for juice, and mature seeds are a source of edible oil and protein (McCreight et al., 1992).

The first accessions of melon germplasm in the U.S. Dept. of Agriculture, Agricultural Research Service, National Plant Germplasm System (NPGS) collection were acquired in 1898. The NPGS melon collection grew to $\approx 2665$ accessions by 1992 (K. Reitsma, unpublished). Melon germplasm from India and Korea provided sources of resistance to numerous diseases and insect pests (McCreight et al., 1992).

A 1987 report from the Cucurbit Crop Germplasm Committee recommended acquisition of additional melon germplasm from the center of origin and the centers of diversity. In 1992, a Cucumis L. germplasm collection expedition in India resulted in the acquisition of $\approx 400$ new accessions of $C$. melo $(\mathrm{McCreight}$ et al., 1993; Staub and McCreight, 2004), while in 1994, a germplasm exchange trip with China acquired 30 additional unique germplasm accessions (Wehner et al., 1995).

Genetic markers have been used to assess genetic diversity and determine taxonomic relationships in melon (Staub et al., 2000; Stepansky et al., 1999; Torres-Ruiz and Hemleben, 1991; Zentgraf et al., 1992). Neuhausen (1992) used restriction fragment-length polymorphisms to discriminate melon cultivars. More recently, Staub et al. (2000) used random amplified polymorphic DNA (RAPD) and simple-sequence repeat markers to assess genetic variation among a diverse array of melon market classes.

Isozyme and RAPD loci were equally effective in defining the genetic relationships among different U.S. market class melons (Staub et al., 1997), and can allow for descriptive analysis of melons of diverse origins (Esquinas-Alcazar, 1981). Recently, Akashi et al. (2002) used five enzyme systems (nine loci), seed size, and germinability under wet conditions to describe the genetic variation and phylogenetic relationships among eastern 
and southern Asian melons. They compared Asian accessions from Myanmar, Laos, China, Korea, and Japan to accessions from India originating from distinct geographic regions (i.e., eastern, northern, western, southern, and central states). Their data indicate that Indian melons were rich in genetic diversity, and that this diversity decreased from India towards the east. Akashi et al. (2002) examined 21 of the $\approx 400$ accessions that were collected during the U.S./India expedition of 1992 (McCreight et al., 1993; Staub and McCreight, 1993), but none of the 30 accessions acquired by the U.S./China expedition in 1994. Given the relatively small number of Indian accessions examined by Akashi et al. (2002), the comparatively large genetic diversity detected in Indian germplasm, and the rather dramatic genetic differences recorded between Indian and Chinese germplasm, we decided to conduct a more extensive assessment of the genetic diversity in Indian melon. We previously characterized 19 isozyme loci in melon (Staub et al., 1998), and determined that variation detected by these loci is useful for describing population structure in melon (Staub et al., 1997). Thus, we used these 19 isozyme loci to assess the genetic variation among recently collected melon accessions from India (states of Rajasthan, Madhya Pradesh, and Uttar Pradesh), and China acquired during the U.S./India 1992 and U.S./China 1994 expeditions. The comparative analysis of these accessions in conjunction with reference accessions allowed for a rigorous assessment of their genetic distinctiveness and the characterization of important genetic relationships among these potentially important collections.

\section{Materials and Methods}

Germplasm. Three hundred seventy-eight $C$. melo plant introductions (PIs) obtained from the U.S. Dept. of Agriculture, North Central Regional Plant Introduction Station (NCRPIS), Ames, Iowa, were surveyed for variation at 19 polymorphic isozyme loci in 13 enzyme systems (Staub, 2003; Staub et al., 1998). In order to simplify terminology according to groupings in previous work (Mliki et al., 2001; Staub et al., 2000) and to allow for comparative analysis of reference accessions from these studies, we designate these varieties herein as botanical groups (i.e., Group Cantalupensis and Inodorus). Experimental germplasm included both melon subspecies: 104 accessions identified as $C$. melo ssp. agrestis, and 274 were taxonomically C. melo ssp. melo by the NCRPIS. Subspecies agrestis is considered to be a wild, feral form of $C$. melo that is occasionally cultivated. Subspecies melo contains the cultivated botanical groups, Cantalupensis, Conomon, and Inodorus (Robinson and Decker-Walters, 1997). Twenty-six accessions originated from People's Republic of China of which seven were acquired prior to 1994, and 19 in 1994 during a joint U.S./China expedition (Wehner et al., 1995), and 352 accessions were collected from India in 1992 (McCreight et al., 1993). The U.S. cultivars Top Mark and Green Flesh Honeydew were included as reference accessions and are representative of two distinct major cultivar-groups of $C$. melo ssp. melo grown in the United States, Cantalupensis and Inodorus, respectively (Staub et al., 1997, 2000).

Accessions were given specific identification numbers with prefixes to indicate country and city or area of origin for graphic depiction of genetic relationships, such as $\mathrm{CHa}$ (China, Harbin), CHe (China, Henan), CK (China, Kwangsi), CM (China, Manchuria), CT (China, Tianjin), CSh (China, Shanghai), CSx (China, Shaanxi), CX (China, Xinjiang), IG (India, Gujarat), IM (India, Madhya Pradesh), and IR (India, Rajasthan).
SAMPLE PREPARATION AND ELECTROPHORESIS. Cotyledons of 15 individuals from each accession were harvested from 7-d-old seedlings. Samples were bulked for analysis such that $\approx 0.01 \mathrm{~g}$ of cotyledonary tissue from each seedling was ground in $0.1 \mathrm{~mL}$ of a buffer solution containing $0.67 \mathrm{~g} \cdot \mathrm{L}^{-1}$ Tris base and $7.02 \mathrm{~g} \cdot \mathrm{L}^{-1}$ Tris- $\mathrm{HCl}$ at $\mathrm{pH} 7.1$. Plant tissue was held at $5{ }^{\circ} \mathrm{C}(<2 \mathrm{~h})$ before horizontal starch gel electrophoresis was performed according to Knerr and Staub (Knerr and Staub, 1992). Modified staining procedures (Allendorf et al., 1977; Brewer, 1970; Shaw and Prasad, 1970) were used to visualize banding patterns of the 13 enzyme systems examined.

Gels consisted of either 42 or $56 \mathrm{~g}$ of a 1:1:1 mixture of hydrolyzed potato starch from Sigma Co. (St. Louis), Connaught Laboratories (Willowdale, Ont.), and Starch Art (Smithsville, Texas) dissolved in either 300 or $400 \mathrm{~mL}$ of buffer, respectively. Gel and electrode buffers described by Allendorf et al. (1977), Clayton and Tretiak (1972), Ridgway et al. (1970), Market and Faulhaber (1965), and Selander et al. (1971) were used (Table $2)$. These are referred to in the text as $\mathrm{A}(\mathrm{pH} 7.1$ gel, $\mathrm{pH} 7.0$ electrode), $\mathrm{C}$ ( $\mathrm{pH} 6.1$ gel and electrode), $\mathrm{M}(\mathrm{pH} 8.7$ gel, $8.7 \mathrm{pH}$ electrode), R ( $\mathrm{pH} 8.5$ gel, $\mathrm{pH} 8.1$ electrode), and $\mathrm{S}-4$ ( $\mathrm{pH} 6.7$ gel, pH 6.3 electrode), respectively.

ISOZYME LOCI. Isozyme banding patterns were observed using 13 enzyme systems [aconitase (AC), acid phosphatase (ACP), adenylate kinase (AK), fructose diphosphatase (FDP), glucosephosphate isomerase (GPI), isocitrate dehydrogenase (IDH), malate dehydrogenase $(\mathrm{MDH})$, manosephosphate isomerase (MPI), peptidase with glycyl-leucine (PEP-GL), peptidase with leucyl-alanine (PEP-LA), peptidase with phenyl-alanyl-proline (PEP-PAP), 6-phosphgluconate dehydrogenase (PGD), and phosphoglucomutase (PGM)]. 'Top Mark' and 'Green Flesh Honeydew' were used as standards, according to Staub et al. (1997).

Genetic nomenclature follows Knerr and Staub (1992) modified from Richmond (1972). Enzymes are designated as previously described by Staub et al. (1998).

STATISTICAL ANAlYSIS. Statistics of genetic variation [Nei's gene diversity, Shannon's information index, genetic distance (GD), Shannon's information index, heterozygosity, and polymorphism] were calculated using allele frequency estimates obtained from genotypic frequencies of isozyme loci of 380 (378+ 'Top Mark' and 'Green Flesh Honeydew') individuals using POPGENE (Yeh et al., 1997). Allele frequency (p) of codominant isozymes was assumed to be 0.5 in bulked samples of each accession (Staub et al., 1998). The loci examined herein possessed two alleles and the heterogeneous nature of the germplasm allows for the presence of both heterozygotes and homozygotes in bulk samples (LopezSese et al., 2002). Estimates of allele frequencies were calculated according to the protocol of Widrlechner et al. (1992).

Isozyme frequency data were used to calculate GD estimates according to Nei (Nei, 1973, 1978) using the NTSYS-pc program version 1.8 (Rohlf, 1997). Unweighted pair-group method using arithmetic average (UPGMA) cluster analyses were performed on the genetic distance matrix to determine the relationships among accessions (dendrograms), and are presented as coefficients of similarity (Yeh et al., 1997). The UPGMA algorithm assumes constant evolutionary rates, and it is believed that in the recent evolutionary past that the rates of evolution have been similar in each agricultural system, i.e., India and China.

Serial and step-wise cluster analyses were employed initially for exploratory examination of genetic variation, and then subsequently for data reduction (Chatfield and Collins, 1980). This was accomplished using a three-step strategy (Steps 1-3) where 
initially all accessions (378) were partitioned into groups based on their genetic similarity (Step 1). A random candidate accession was chosen to represent a group of identical accessions (i.e., GD value in pairwise comparison was 0 , for subsequent cluster analyses). A second cluster analysis (Step 2) was performed on this selected group of accessions (148 including 'Top Mark' and 'Green Flesh Honeydew') resulting in distinct branches. To provide a simple pictorial description of the genetic relationships among groups, a third cluster analysis (Step 3) was performed using representative samples (between 2 to 5 depending on group size) of each of the groups identified in Step 2. In this final step, a Nei's GD of 0.16 was chosen as a threshold for grouping accessions for further data reduction. This Nei's GD was chosen based on visual inspection of branches, and a comparative assessment of relationships among accessions between and within branches. The application of this threshold allowed for the elimination of accessions with considerable genetic similarities, and resulted in a dendrogram descriptive of the most distinctive groupings in the data set. Data sets, genetic distance matrices, and cluster groupings of reduction Step 1 (from 378 to 146 accessions) are available online (Staub, 2003). Other multivariate techniques such as discriminant function analysis could have been used as an adjunct to the exploratory analysis provided by the cluster analysis employed herein (Sokal and Sneath, 1963). However, the intent of this work was to specifically identify genetic relationships among Indian and Chinese accessions examined, and not extrapolate to possible genetic lineages or evolutionary relationships. Thus, more sophisticated statistical metrics were not used.

\section{Results}

Differences among accessions resulted from presence of polymorphisms and differences in allelic frequencies. Stepwise reduction of the initial data set (Step 1-3) resulted in the eventual identification of 11 distinct groups containing genetically similar accessions. Six isozyme loci (Ac, Fdp-1, Mdh-4, Mdh-5, Pgm-1, and $S k d h$ ) were important in elucidating major groups in data set reduction Step 1 (data not presented). The initial cluster analysis resulted in the grouping of accessions into 148 groups of varying size with the number of accessions per group ranging from 2 to 47 . Some groups were relatively homogeneous containing only accessions originating from either China or India, or from a particular state, city, or province. Other groups were more heterogeneous for geographic origin and/or subspecies.

Based on relative GD values, the initial data set of 380 accessions was reduced to 148 (146 accessions + 'Top Mark' and 'Green Flesh Honeydew') accessions (Table 1). The data set containing these accessions was subjected to a second cluster analysis to depict genetic relationships (Fig. 1). Seven isozyme loci (example, Ac, Fdp-1, Gpi, Mdh-4, Mdh-5, Pgm-1, and Skdh) were important in elucidating major groups in data set reduction Step 2 (data not presented). The threshold Nei's GD of 0.16 allowed for the identification of 11 groups of accessions (nodes 1-10) in reduction Step 3.

The initial partitioning of the 380 accessions resulted in the identification of two unique $C$. melo ssp. agrestis accessions (IR 106; IR I07) (Group 1; Table 1; Fig. 1) from Rajasthan, India. These accessions were genetically distinct, and unique in the degree of fixation at the 13 loci examined (13 fixed in IR106, and 12 fixed loci and one heterozygous locus in IR107). IR106 and IR107 were two of 32 single-fruit collections (nine of subspecies agrestis and
23 of subspecies melo) purchased at a market in the city of Pali in the Pali District of Rajasthan. All of these fruit collected were reportedly from Kirakiduhandi, in the Pali District.

Separation at node 2 (Nei's GD $=0.250$ ) resulted in the formation of two large branches in which one branch was further partitioned into three groupings (2, 3, and 4) at nodes 3 (Nei's GD $=0.208$ ) and 4 (Nei's GD =0.178). Group 2 was comprised of three accessions, IR20, IM126, IM129, which are not representative of any other accessions. IR20 (subspecies melo) was one of 62 fruit collected from a sand dune near Sriramsar, Bikaner District, Rajasthan. IM126 and IM129 (both subspecies agrestis) were collected in different districts, East Nimar and Dhar, respectively. While 11 of the 13 loci in IM126 and IM129 are homozygous, the remaining two loci are heterozygous. Group 3 consisted of 11 subspecies agrestis and one subspecies melo accessions. All 13 loci in IR71 (subspecies agrestis) are homozygous. While Group 3 consisted solely of accessions from Rajasthan, Group 4 was a heterogeneous mixture of 34 accessions (14 subspecies agrestis, 20 subspecies melo) from 14 districts in Rajasthan and Madhya Pradesh. Groups 3 and 4 were representative of 19 and 76 accessions after reduction Step 1, respectively.

The second large branch contained seven groups of accessions ( 5 to 11 ) that were separated at nodes 5 (Nei's GD =0.235), 6 (Nei's GD = 0.203), 7 (Nei's GD = 0.214), 8 (Nei's GD = 0.200), 9 (Nei's GD = 0.184), and 10 (Nei's GD = 0.162). Groups 5, 6, 7, $8,9,10$, and 11 consisted of $2,14,2,3,16,13$, and 47 accessions, respectively, and were representative of 2, 24, 2, 3, 34, 24, and 182 accessions, respectively, after Step 1.

While Group 5 consisted only of subspecies agrestis, Groups 7,8 , and 10 consisted only of subspecies melo accessions, and Groups 6, 9, and 11 were mixtures of both subspecies. Group 5 consisted solely of two unique agrestis accessions (IM155 and IM156) from the same site in the Indore District of Madhya Pradesh. Group 6 contained 12 Indian accessions (eight from seven sites in Rajasthan and four from four sites in Madhya Pradesh) and two Chinese accessions [CSx189 (subspecies agrestis) and CSx176 (subspecies melo)]. Group 6 is representative of accessions from Rajasthan (14), Madhya Pradesh (6), Shaanxi (2), and Xinjiang (2). The Indian accessions were a mixture of two subspecies agrestis accessions from two sites and 10 subspecies melo accessions from nine sites. Two unique subspecies melo accessions from Madhya Pradesh (IM151 and IM194) comprised Group 7. Likewise, the three subspecies melo accessions (IR45, IM120, and IM159) forming cluster Group 8 were unique and not representative of any other accessions. 'Top Mark' and 'Green Flesh Honeydew' clustered with a mixture of 12 Indian accessions obtained from Rajasthan (5), Madhya Pradesh (6), and Gujarat (1), and two Chinese accessions from Xinjiang (CX178) and Harbin (CH184) to comprise Group 9, representative of a total of 34 accessions ( $1 \mathrm{CH}, 1 \mathrm{CM}, 6 \mathrm{CX}, 1 \mathrm{IG}, 14 \mathrm{IM}$, 9 IR, 'Top Mark' and 'Green Flesh Honeydew'). While three accessions in Group 9, IR7, IR105, and IG110, are subspecies agrestis, the remaining accessions were subspecies melo. Group 10 consisted of 13 subspecies melo accessions, six Indian [Rajasthan (3), Madhya Pradesh (3)], and seven Chinese [Henan (1), Shaanxi (3), Shanghai (3)]. These were representative of a total of 24 accessions (4 Rajasthan, 10 Madhya Pradesh, 1 Henan, 3 Shaanxi, 4 Shanghai, 2 Xinjiang) after initial reduction. Group 11 consisted of 36 subspecies melo and 11 subspecies agrestis accessions acquired from Rajasthan (37), Madhya Pradesh (7), Manchuria (1), Kwangsi (1), and Xinjiang (1), these accessions were representative of a total of 190 accessions. 
Table 1. One hundred forty-eight melon (Cucumis melo) accessions assessed for variation at 19 isozyme loci.

\begin{tabular}{|c|c|c|c|c|c|c|c|c|c|c|c|}
\hline $\begin{array}{l}\text { ID } \\
\text { no. }\end{array}$ & $\begin{array}{l}\text { Plant } \\
\text { introd. }\end{array}$ & $\begin{array}{c}\text { Sub- } \\
\text { species }^{y}\end{array}$ & $\begin{array}{l}\text { Cluster } \\
\text { group }^{x}\end{array}$ & $\begin{array}{l}\text { ID } \\
\text { no. }\end{array}$ & $\begin{array}{l}\text { Plant } \\
\text { introd. }\end{array}$ & $\begin{array}{c}\text { Sub- } \\
\text { species }\end{array}$ & $\begin{array}{l}\text { Cluster } \\
\text { group }\end{array}$ & $\begin{array}{l}\text { ID } \\
\text { no. }\end{array}$ & $\begin{array}{c}\text { Plant } \\
\text { introd. }\end{array}$ & $\begin{array}{c}\text { Sub- } \\
\text { species }\end{array}$ & $\begin{array}{l}\text { Cluster } \\
\text { group }\end{array}$ \\
\hline$\overline{\mathrm{IR} 1}$ & PI 614161 & $\mathrm{~m}$ & 11 & IR60 & PI 614331 & $\mathrm{~m}$ & 11 & IM123 & PI 614512 & $\mathrm{a}$ & 11 \\
\hline IR3 & PI 614163 & $\mathrm{~m}$ & 11 & IR62 & PI 614336 & $\mathrm{~m}$ & 11 & IM124 & PI 614513 & $\mathrm{~m}$ & 10 \\
\hline IR4 & PI 614164 & $\mathrm{~m}$ & 6 & IR63 & PI 614338 & $\mathrm{~m}$ & 11 & IM126 & PI 614516 & $\mathrm{a}$ & 2 \\
\hline IR5 & PI 614166 & $\mathrm{~m}$ & 11 & IR64 & PI 614339 & $\mathrm{~m}$ & 11 & IM128 & PI 614523 & $\mathrm{a}$ & 11 \\
\hline IR6 & PI 614167 & $\mathrm{~m}$ & 11 & IR67 & PI 614350 & $\mathrm{~m}$ & 11 & IM129 & PI 614525 & $\mathrm{a}$ & 2 \\
\hline IR7 & PI 614173 & $\mathrm{a}$ & 9 & IR68 & PI 614352 & $\mathrm{~m}$ & 6 & IM130 & PI 614526 & $\mathrm{a}$ & 4 \\
\hline IR8 & PI 614173 & $\mathrm{a}$ & 11 & IR69 & PI 614353 & $\mathrm{~m}$ & 9 & IM133 & PI 614531 & $\mathrm{a}$ & 4 \\
\hline IR10 & PI 614178 & $\mathrm{~m}$ & 11 & IR70 & PI 614354 & $\mathrm{a}$ & 11 & IM134 & PI 614532 & $\mathrm{a}$ & 11 \\
\hline IR11 & PI 614180 & $\mathrm{~m}$ & 11 & IR71 & PI 614355 & $\mathrm{a}$ & 3 & IM135 & PI 614535 & $\mathrm{~m}$ & 9 \\
\hline IR12 & PI 614182 & $\mathrm{~m}$ & 4 & IR72 & PI 614356 & $\mathrm{a}$ & 3 & IM137 & PI 614540 & $\mathrm{a}$ & 6 \\
\hline IR13 & PI 614186 & $\mathrm{~m}$ & 6 & IR73 & PI 614358 & $\mathrm{~m}$ & 11 & IM141 & PI 614549 & $\mathrm{a}$ & 11 \\
\hline IR14 & PI 614198 & $\mathrm{~m}$ & 11 & IR74 & PI 614359 & $\mathrm{a}$ & 3 & IM142 & PI 614550 & $\mathrm{a}$ & 4 \\
\hline IR15 & PI 614201 & $\mathrm{~m}$ & 10 & IR75 & PI 614360 & $\mathrm{a}$ & 4 & IM143 & PI 614559 & $\mathrm{~m}$ & 9 \\
\hline IR16 & PI 614205 & $\mathrm{~m}$ & 11 & IR76 & PI 614361 & $\mathrm{a}$ & 3 & IM144 & PI 614561 & $\mathrm{~m}$ & 6 \\
\hline IR17 & PI 614213 & $\mathrm{~m}$ & 11 & IR77 & PI 614362 & $\mathrm{a}$ & 3 & IM146 & PI 614563 & $\mathrm{a}$ & 4 \\
\hline IR18 & PI 614220 & $\mathrm{~m}$ & 4 & IR78 & PI 614363 & $\mathrm{a}$ & 11 & IM147 & PI 614567 & $\mathrm{~m}$ & 11 \\
\hline IR19 & PI 614221 & $\mathrm{~m}$ & 4 & IR79 & PI 614364 & $\mathrm{a}$ & 3 & IM151 & PI 614572 & $\mathrm{~m}$ & 7 \\
\hline IR20 & PI 614222 & $\mathrm{~m}$ & 2 & IR80 & PI 614365 & $\mathrm{a}$ & 3 & IM152 & PI 614573 & $\mathrm{a}$ & 6 \\
\hline IR21 & PI 614223 & $\mathrm{~m}$ & 4 & IR82 & PI 614368 & $\mathrm{a}$ & 11 & IM154 & PI 614579 & $\mathrm{a}$ & 6 \\
\hline IR22 & PI 614225 & $\mathrm{~m}$ & 4 & IR83 & PI 614371 & $\mathrm{~m}$ & 4 & IM155 & PI 614580 & $\mathrm{a}$ & 5 \\
\hline IR23 & PI 614226 & $\mathrm{~m}$ & 4 & IR85 & PI 614378 & $\mathrm{~m}$ & 4 & IM156 & PI 614581 & $\mathrm{a}$ & 5 \\
\hline IR24 & PI 614228 & $\mathrm{~m}$ & 4 & IR88 & PI 614386 & $\mathrm{~m}$ & 11 & IM157 & PI 614582 & $\mathrm{~m}$ & 10 \\
\hline IR25 & PI 614229 & $\mathrm{~m}$ & 4 & IR89 & PI 614386 & $\mathrm{~m}$ & 11 & IM158 & PI 614583 & $\mathrm{~m}$ & 9 \\
\hline IR26 & PI 614230 & $\mathrm{~m}$ & 4 & IR91 & PI 614391 & $\mathrm{a}$ & 3 & IM159 & PI 614585 & $\mathrm{~m}$ & 8 \\
\hline IR27 & PI 614233 & $\mathrm{~m}$ & 4 & IR92 & PI 614392 & $\mathrm{a}$ & 11 & IM160 & PI 614586 & $\mathrm{~m}$ & 9 \\
\hline IR28 & PI 614234 & $\mathrm{~m}$ & 4 & IR93 & PI 614393 & $\mathrm{a}$ & 3 & IM164 & PI 614596 & $\mathrm{~m}$ & 9 \\
\hline IR29 & PI 614235 & $\mathrm{~m}$ & 6 & IR94 & PI 614396 & $\mathrm{a}$ & 4 & IM165 & PI 614597 & $\mathrm{~m}$ & 11 \\
\hline IR30 & PI 614237 & $\mathrm{~m}$ & 11 & IR95 & PI 614399 & $\mathrm{a}$ & 3 & IM167 & PI 614600 & $\mathrm{~m}$ & 10 \\
\hline IR31 & PI 614239 & $\mathrm{~m}$ & 4 & IR96 & PI 614401 & $\mathrm{~m}$ & 6 & IM168 & PI 614601 & $\mathrm{~m}$ & 10 \\
\hline IR33 & PI 614242 & $\mathrm{~m}$ & 11 & IR98 & PI 614409 & $\mathrm{a}$ & 11 & CS169 & PI 618822 & $\mathrm{~m}$ & 10 \\
\hline IR34 & PI 614243 & $\mathrm{~m}$ & 11 & IR99 & PI 614412 & $\mathrm{a}$ & 3 & CS170 & PI 618825 & $\mathrm{~m}$ & 10 \\
\hline IR35 & PI 614244 & $\mathrm{~m}$ & 6 & IR100 & PI 614414 & $\mathrm{a}$ & 3 & CS171 & PI 618826 & $\mathrm{~m}$ & 10 \\
\hline IR36 & PI 614245 & $\mathrm{~m}$ & 4 & IR101 & PI 614342 & $\mathrm{~m}$ & 4 & $\mathrm{CHe} 172$ & PI 618827 & $\mathrm{~m}$ & 10 \\
\hline IR37 & PI 614252 & $\mathrm{~m}$ & 4 & IR102 & PI 614425 & $\mathrm{~m}$ & 4 & CSx 173 & PI 618828 & $\mathrm{~m}$ & 10 \\
\hline IR38 & PI 614253 & $\mathrm{~m}$ & 11 & IR103 & PI 614428 & $\mathrm{a}$ & 4 & CSx 174 & PI 618831 & $\mathrm{~m}$ & 10 \\
\hline IR39 & PI 614256 & $\mathrm{~m}$ & 9 & IR105 & PI 614432 & $\mathrm{a}$ & 9 & CSx 175 & PI 618833 & $\mathrm{~m}$ & 10 \\
\hline IR43 & PI 614275 & $\mathrm{~m}$ & 4 & IR106 & PI 614433 & $\mathrm{a}$ & 1 & CSx 176 & PI 618834 & $\mathrm{~m}$ & 6 \\
\hline IR44 & PI 614276 & $\mathrm{~m}$ & 11 & IR107 & PI 614435 & $\mathrm{a}$ & 1 & CX178 & PI 618838 & $\mathrm{~m}$ & 9 \\
\hline IR45 & PI 614281 & $\mathrm{~m}$ & 8 & IR108 & PI 614436 & $\mathrm{a}$ & 11 & CX180 & PI 618840 & $\mathrm{~m}$ & 11 \\
\hline IR47 & PI 614289 & $\mathrm{~m}$ & 11 & IR109 & PI 614437 & $\mathrm{a}$ & 4 & IR183 & PI 614602 & $\mathrm{~m}$ & 4 \\
\hline IR48 & PI 614301 & $\mathrm{~m}$ & 11 & IG110 & PI 614440 & $\mathrm{a}$ & 9 & CH184 & PI 93438 & $\mathrm{~m}$ & 9 \\
\hline IR49 & PI 614304 & $\mathrm{~m}$ & 4 & IR111 & PI 614448 & $\mathrm{~m}$ & 11 & CM187 & PI 136186 & $\mathrm{~m}$ & 11 \\
\hline IR50 & PI 614305 & $\mathrm{~m}$ & 11 & IR114 & PI 614455 & $\mathrm{~m}$ & 6 & CG188 & PI 157070 & $\mathrm{~m}$ & 11 \\
\hline IR51 & PI 614306 & $\mathrm{~m}$ & 6 & IR115 & PI 614459 & $\mathrm{~m}$ & 11 & CSx 189 & PI 532829 & $\mathrm{a}$ & 6 \\
\hline IR52 & PI 614308 & $\mathrm{a}$ & 4 & IM117 & PI 614481 & $\mathrm{a}$ & 4 & IM193 & PI $614584 ?$ & $\mathrm{~m}$ & 11 \\
\hline IR53 & PI 614311 & $\mathrm{~m}$ & 10 & IM118 & PI 614486 & $\mathrm{a}$ & 4 & IM194 & PI $614584 ?$ & $\mathrm{~m}$ & 7 \\
\hline IR54 & PI 614313 & $\mathrm{~m}$ & 9 & IM119 & PI 614494 & $\mathrm{a}$ & 4 & GFHD & & $\mathrm{m}$ & 9 \\
\hline IR55 & PI 614322 & $\mathrm{~m}$ & 11 & IM120 & PI 614505 & $\mathrm{~m}$ & 8 & $\mathrm{TM}$ & & $\mathrm{m}$ & 9 \\
\hline IR57 & PI 614326 & $\mathrm{~m}$ & 11 & IM121 & PI 614509 & $\mathrm{~m}$ & 9 & & & & \\
\hline IR58 & PI 614327 & $\mathrm{a}$ & 4 & IR122 & PI 614511 & $\mathrm{~m}$ & 11 & & & & \\
\hline
\end{tabular}

zID no. (identification number) includes country of origin and region: $\mathrm{CG}=\mathrm{China}$, Guangxi $; \mathrm{CH}=\mathrm{China}, \mathrm{Harbin} ; \mathrm{CHe}=\mathrm{China}, \mathrm{Henan} ; \mathrm{CM}=$ China, Manchuria; CS = China, Shanghai; CSx = China, Shaanxi; CX = China, Xinjiang; IG = India, Gujarat; IM = India, Madhya Pradesh; IR = India, Rajasthan; GFHD = 'Greenflesh Honeydew'; TM = 'Top Mark'.

yspecies coded: $\mathrm{a}=$ C. melo ssp. agrestis; $\mathrm{m}=$ C. melo ssp. melo.

xRefer to Fig. 2. 


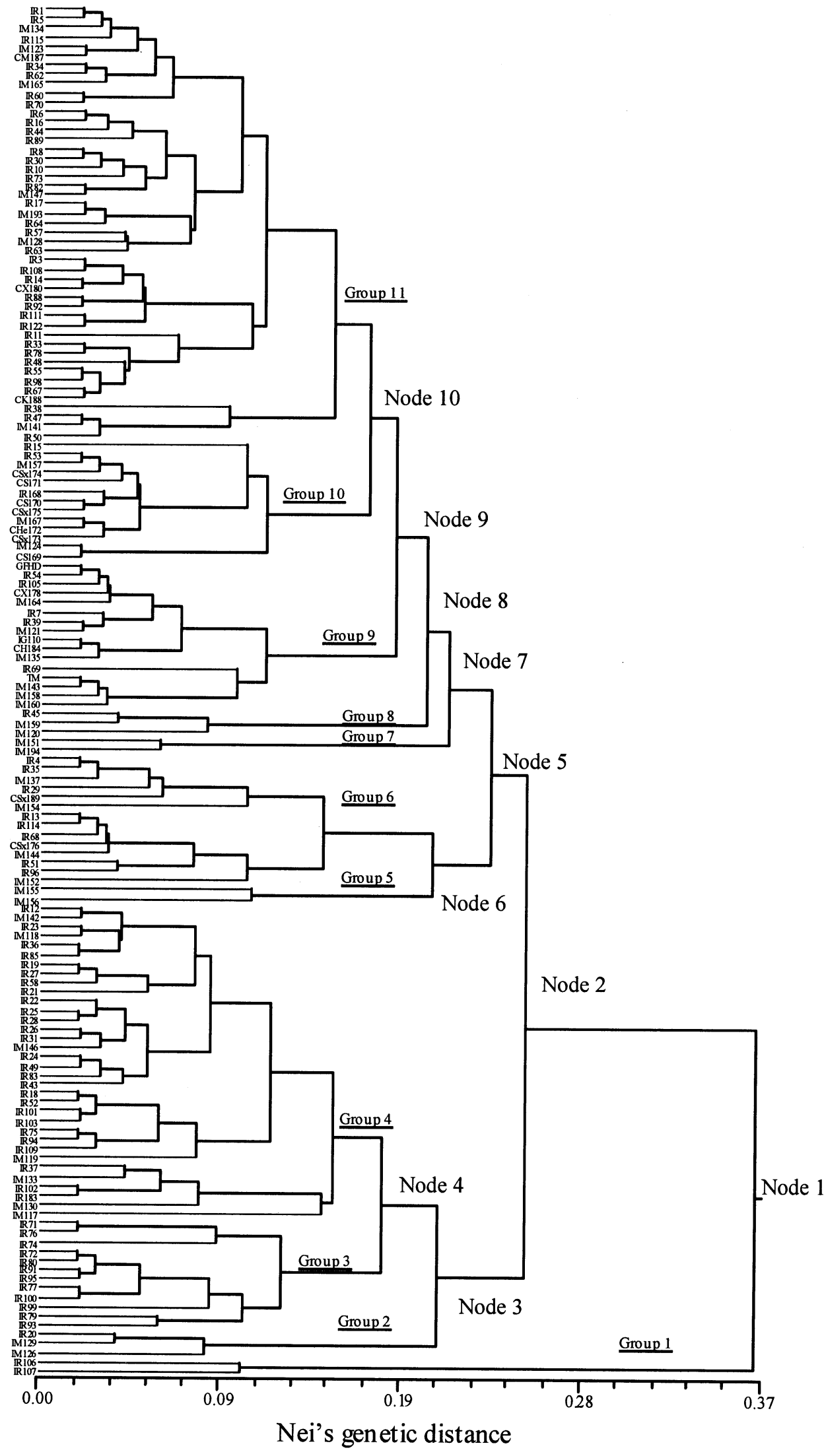

Fig. 1. Cluster analysis (UPGMA) of 148 Cucumis melo accessions grouped by using 19 enzyme loci as framing criteria by Nei's genetic distance estimation (Nei, 1978).
A third cluster analysis using two to five representatives of each of the 11 cluster groupings provided a simple depiction of genetic relationships of the original 380 accessions (Fig. 2; Step 3). Cluster groupings 3 and 4 have genetic affinities and are associated with Group 2 (Table 2). These groups share loose genetic affinities with Groups 7 to 11, but are more similar to each other than to accessions in Groups 5 and 6.

STRuCture of ACCESSION GROUPS. Albeit accession numbers in cluster groupings varied, the percentage of polymorphic loci was relatively low in Groups 1(15.4\%),2(23.1\%),5(23.1\%), $7(23.1 \%)$, and $8(23.1 \%)$ (Table 3$)$. This contrasts with the relatively high levels of genetic diversity and low information indices (Shannon and Weaver, 1949) calculated for these groups when compared to other groups examined. Pair-wise GD estimates of accessions in Groups 1, 2, 5, 7, and 8 were also higher than those of other groups (Tables 2 and 3). With rare exception (Group 7), the observed heterozygosity was lower than expected in all groups.

Group 11 possessed the highest percent polymorphic loci, $92.3 \%$, (Table 3). Groups 3, 6, 9, and 10 moderately high polymorphism levels. Accessions in Group 11 were not exceptionally diverse (estimates of $h$, observed heterozygosity and/or GD) (Tables 2 and 3). Although Group 4 accessions possessed moderately high levels of enzyme polymorphisms (76.9\%), GDs between accessions and observed heterozygosity levels were less than those in Group 11. The level of genetic diversity among accessions in Group 1 was comparatively less than that recorded in the other groups analyzed [observed heterozygosity (0.039) and \% polymorphic loci (15.4\%)]. However, the genetic distances among accessions in this group varied widely, where maximum "within-group" distances were relatively large $(\mathrm{GD}=0.50)$.

\section{Discussion}

India is regarded as the primary center of diversity for melons (Robinson and Decker-Walters, 1997). Melons were transported from India eastward to China (secondary center of diversity) and westward through southern Asia, from the Middle East to Europe, and then eventually to the Americas (Robinson 


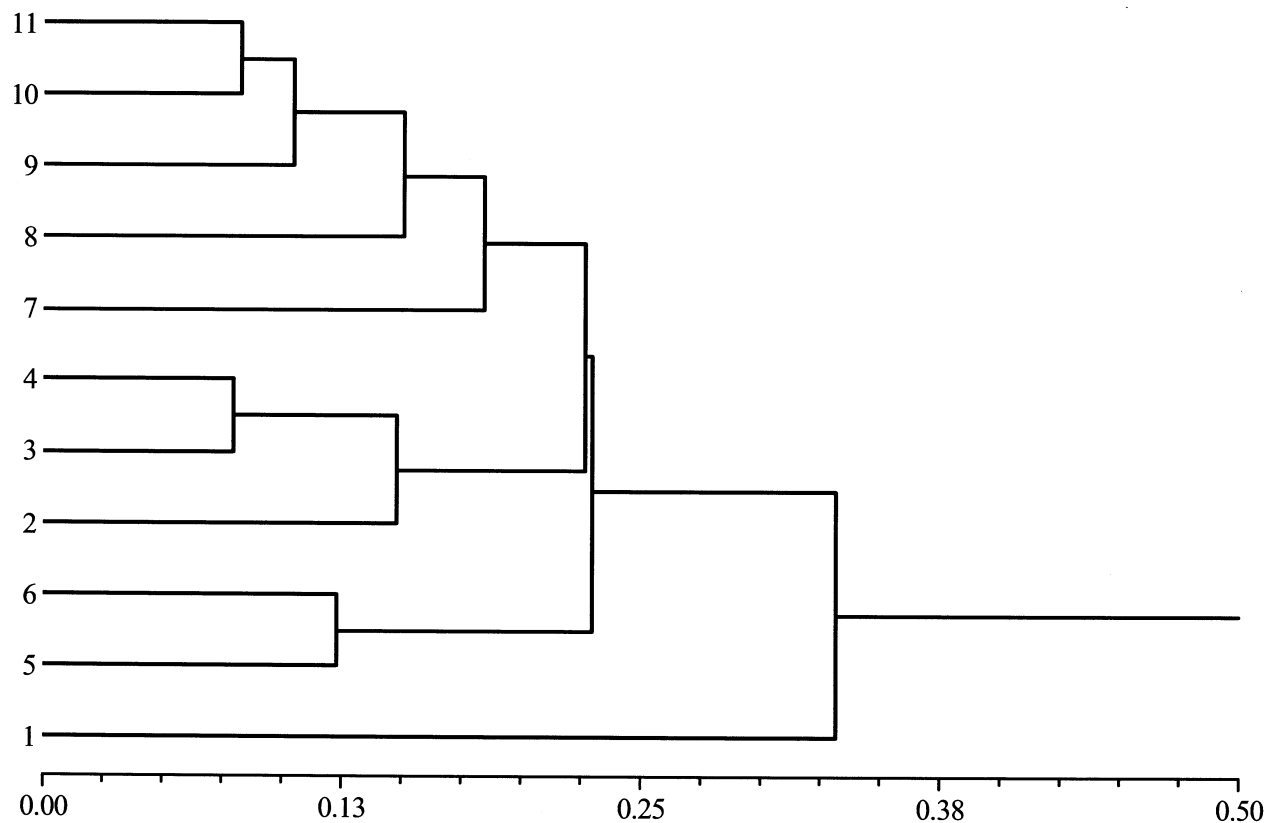

Nei's genetic distance

Fig. 2. Cluster analysis (UPGMA) of 11 groups of Cucumis melo accessions (148 examined) as defined in Fig. 1 and grouped by using 19 enzyme loci as framing criteria by Nei’s genetic distance estimation (Nei, 1978)

and Decker-Walters, 1997). The United States is a relatively recent recipient of a small array of melon cultivar-groups and varieties, mostly from Europe. In the United States, the initially restricted genetic base of melon is being further narrowed through plant breeding and $F_{1}$ hybrid development. Likewise, the genetic base of cultivated melons in breeding programs in China and Japan is being diminished as a result of hybrid cultivation (Chen, 2002). As disease and pest problems become more common worldwide, resistant Indian and Eastern Asian germplasm is being incorporated into modern cultivars of several cultivar-groups (Bohn et al., 1980; Lecoq and Pitrat, 1982; Lopez-Sese and Gomez-Guillamon, 2000; McCreight, 1998; McCreight et al., 1987, 1984), e.g., Cantalupensis and Inodorus, each of which consist of a wide array of market types adapted to different production systems.

Examination of variation at 19 isozyme loci of recently acquired germplasm from China and India (378 accessions) indicated that 132 Indian accessions exhibited greater genetic diversity than the 14 Chinese accessions, and two U.S. reference accessions. 'Top Mark' and 'Green Flesh Honeydew' represent two distinct cultivar-groups of subspecies melo. 'Top Mark' typifies genetic variation in the Cantalupensis Group where plants produce completely netted, orange flesh, sweet, climacteric fruit that abscise at maturity. In contrast, 'Green Flesh Honeydew' typifies the Inodorus Group (wintermelon), which produces nonnetted, green flesh, sweet, nonclimacteric fruit that do not abscise. Despite these dramatic horticultural differences, 'Top Mark' and 'Green Flesh Honeydew' showed genetic affinities (Group 9), and unique differences when compared to other accessions in their group. Two Chinese accessions known for their relatively sweet flesh clustered in Group 9 with 'Top Mark' and 'Green Flesh Honeydew'. Accession CX178, described by Chinese investigators as a "Hami" type (Inodorus Group), which typically possesses heavy net at the stem-end of the fruit that is yellow with green spots, was closely related to 'Green Flesh Honeydew' (Fig. 1). Accession CH184 was also more closely related to 'Green Flesh Honeydew' than to 'Top Mark'.

The seven Chinese accessions in Group 10 originate from three provinces with different climatic conditions (Henan, Shaanxi, and Shanghai). These white or green flesh melons are thin-skinned, "sweet" melons with a relatively short shelf life. Accession CS169 is a landrace that has been cultivated in P.R. China for more than 400 years.

The three Chinese melons in Group 11 originated from three regions (Guangxi Zhuangzu, Manchuria, and Xinjiang). The landrace accession CX180 produces sweet, relatively small oblate

Table 2. Genetic variability measures for 11 melon (Cucumis melo) cluster groupings as calculated by variation at 19 isozyme loci.

\begin{tabular}{|c|c|c|c|c|c|c|c|c|c|c|}
\hline \multirow[b]{2}{*}{ Group } & \multirow{2}{*}{$\begin{array}{l}\text { Accessions } \\
\text { (no.) }\end{array}$} & \multirow{2}{*}{$\begin{array}{c}\text { Poly- } \\
\text { morphism }(\%)^{\mathrm{x}}\end{array}$} & \multicolumn{4}{|c|}{ Genetic distances ${ }^{\mathrm{z}}$} & \multirow{2}{*}{$\begin{array}{c}\text { Shannon's } \\
\text { Iw }^{w}\end{array}$} & \multicolumn{2}{|c|}{ Heterozygosityy } & \multirow{2}{*}{$\begin{array}{l}\text { Nei's expected } \\
\text { heterozygosity }\end{array}$} \\
\hline & & & $\mathrm{D}$ & Minimum & Maximum & $\overline{\mathrm{SD}}$ & & $\mathrm{H}_{\mathrm{O}}$ & $\overline{\mathrm{H}_{\mathrm{E}}}$ & \\
\hline 1 & 2 & 15.4 & 0.332 & 0.127 & 0.500 & 0.118 & 0.097 & 0.039 & 0.090 & 0.067 \\
\hline 2 & 3 & 23.1 & 0.253 & 0.110 & 0.371 & 0.079 & 0.137 & 0.103 & 0.113 & 0.094 \\
\hline 4 & 34 & 76.9 & 0.160 & 0.080 & 0.233 & 0.057 & 0.248 & 0.113 & 0.153 & 0.151 \\
\hline 5 & 2 & 23.1 & 0.287 & 0.123 & 0.427 & 0.095 & 0.150 & 0.115 & 0.141 & 0.106 \\
\hline 6 & 14 & 61.5 & 0.174 & 0.099 & 0.252 & 0.051 & 0.216 & 0.077 & 0.134 & 0.129 \\
\hline 8 & 3 & 23.1 & 0.244 & 0.098 & 0.500 & 0.107 & 0.137 & 0.103 & 0.113 & 0.094 \\
\hline 9 & 16 & 53.9 & 0.204 & 0.086 & 0.386 & 0.097 & 0.187 & 0.082 & 0.116 & 0.112 \\
\hline 10 & 13 & 46.2 & 0.206 & 0.083 & 0.324 & 0.075 & 0.181 & 0.101 & 0.115 & 0.110 \\
\hline 11 & 47 & 92.3 & 0.147 & 0.083 & 0.345 & 0.081 & 0.256 & 0.121 & 0.154 & 0.152 \\
\hline
\end{tabular}

¿Unbiased Nei's genetic distance, $\mathrm{D}=$ mean (Nei, 1973).

${ }^{\mathrm{y}} \mathrm{H}_{\mathrm{O}}=$ observed, $\mathrm{H}_{\mathrm{E}}=$ expected (Levene, 1949).

Percentage of polymorphic loci.

wI = Shannon's information index (Shannon and Weaver, 1949).

vNei's expected heterozygosity (Nei, 1973). 
Table 3. Nei's genetic distance measures among 11 cluster groupings in melon (Cucumis melo) as determined by variation at 19 isozyme loci.

\begin{tabular}{|c|c|c|c|c|c|c|c|c|c|c|c|}
\hline \multirow[b]{2}{*}{ Group } & \multicolumn{11}{|c|}{ Group } \\
\hline & $\overline{1}$ & 2 & 3 & 4 & 5 & 6 & 7 & 8 & 9 & 10 & 11 \\
\hline 1 & 0 & 0.370 & 0.126 & 0.233 & 0.426 & 0.252 & 0.453 & 0.500 & 0.386 & 0.224 & 0.345 \\
\hline 2 & & 0 & 0.188 & 0.110 & 0.320 & 0.217 & 0.301 & 0.239 & 0.305 & 0.302 & 0.183 \\
\hline 3 & & & 0 & 0.080 & 0.294 & 0.188 & 0.258 & 0.294 & 0.250 & 0.266 & 0.180 \\
\hline 4 & & & & 0 & 0.220 & 0.133 & 0.223 & 0.194 & 0.131 & 0.176 & 0.098 \\
\hline 5 & & & & & 0 & 0.123 & 0.416 & 0.291 & 0.277 & 0.324 & 0.181 \\
\hline 6 & & & & & & 0 & 0.201 & 0.220 & 0.123 & 0.181 & 0.099 \\
\hline 7 & & & & & & & 0 & 0.246 & 0.188 & 0.190 & 0.114 \\
\hline 8 & & & & & & & & 0 & 0.172 & 0.184 & 0.098 \\
\hline 9 & & & & & & & & & 0 & 0.126 & 0.086 \\
\hline 10 & & & & & & & & & & 0 & 0.083 \\
\hline 11 & & & & & & & & & & & 0 \\
\hline
\end{tabular}

fruit that possess vein tracts. Fruit are yellow at maturity, and with white flesh and relatively large seeds. Additional, more descriptive passport data are not available for the other two accessions (CG188 and CM187) in this cluster grouping.

The two Chinese accessions included in Group 6 originate from Shaanxi Province (Table 1). These accessions are more closely related to Group 5 than to Groups 7, 8, 9, 10, and 11 (Fig. 1). One of these, accession CSx 176, collected in a vegetable market in the city of Yangling is subspecies melo and carries the local name "sesame seed melo." The other, accession CSx189 is subspecies agrestis.

The 14 Chinese accessions originated from seven climatically different regions of China. However, these were related to only four of the 11 cluster groups that were defined by the 132 accessions from 41 sites in two states of India, Rajsthan and Madhya Pradesh. This may be an artifact of the relatively small number of accessions from China, 14 vs. 132 from India, but there are at least two alternative explanations for this result. It is possible that the variation in Chinese melons as defined by the 19 loci used in this study has been greatly reduced from that found in India. This could have occurred through nonrandom sampling of melons from India, i.e., genetic bottleneck or founder effect potentially leading to genetic drift, or directed selection within the germplasm during breeding, seed increase, or sample collection in China (Chen, 2002).

Another explanation is that the Chinese germplasm examined is more closely related to melons from other northern and/or central regions of India. The genetic variation in the Rajasthan and Madhya Pradesh as detected by isozyme differences may be but a vague representation of the genetic diversity present in eastern, northern and southern India. This explanation is consistent with data of Akashi et al. (2002) who determined that allele frequency changes were associated with geographic regions from India to Asia.

The genetic variability among the 345 Indian melon accessions collected in 1992 as assessed by 19 isozyme loci is relatively large (Tables 2 and 3; Fig. 1), and expands the analysis of Akashi et al. (2002) to more accurately define India germplasm. Moreover, our findings are consistent with their analysis that the western (Rajasthan) and central (Madhya Pradesh) Indian germplasm is rich in genetic variation, and suggests that additional collections of melon germplasm in southern and eastern India could capture genetic diversity not now present in germplasm collections for the future enhancement of melon.

\section{Literature Cited}

Akashi, Y., N. Fukuda, T. Wako, M. Masuda, and K. Kato. 2002. Genetic variation and phylogenetic relationships in East and South Asian melons, Cucumis melo L., based on the analysis of five isozymes. Euphytica 125:385-396.

Allendorf, F.W., N. Mitchell, N. Ryman, and G. Stahl. 1977. Isozyme loci in brown trout (Salmon trutta L): Detection and interpretation from population data. Hereditas 86:179-190.

Bohn, G.W., A.N. Kishaba, and J.D. McCreight. 1980. WMR 29 muskmelon breeding line. HortScience 15:539-540.

Brewer, G.B. 1970. An introduction to isozyme techniques. Academic, New York.

Chatfield, C. and A. J. Collins. 1980. Introduction to multivariate analysis. Chapman and Hall, London.

Chen, J.F. 2002. Major cucurbit crops of China, p. 336-342. In: D.N. Maynard. (ed.). Cucurbitaceae 2002. ASHS Press, Alexandria, Va.

Clayton, J.W. and D.N. Tretiak. 1972. Amine-citrate buffers for $\mathrm{pH}$ control in starch gel electrophoresis. J. Fish Res. Board Can. 29:1169-1172.

Esquinas-Alcazar, J.T. 1981. Alloenzyme variation and relationships among Spanish land-races of Cucumis melo L. Kulturpflanze 29:337-352.

Esquinas-Alcazar, J.T. and P.J. Gulick. 1983. Genetic resources of Cucurbitaceae-A global report. Intl. Board Plant Genetic Resources, Rome.

Jeffrey, C. 1980. A review of the Cucurbitaceae. Bot. J. Linnean Soc. 81:233-247.

Kerje, T. and M. Grum. 2000. The origin of melon, Cucumis melo: A review of the literature. Acta Hort. 510:37-44.

Kirkbride, Jr., J.H. 1993. Biosystematic monograph of the genus Cucumis (Cucurbitaceae): Botanical identification of cucumbers and melons. Parkway Publishers, Boone, N.C.

Knerr, L.D. and J.E. Staub. 1992. Inheritance and linkage relationships of isozyme loci in cucumber (Cucumis sativus L.). Theor. Appl. Genet. 84:217-224.

Lecoq, H. and M. Pitrat. 1982. Use of partial resistance for cucumber mosaic virus control in muskmelon Cucumis melo. Phytoparasitica 10:126-127.

Lopez-Sese, A.I. and M.L. Gomez-Guillamon. 2000. Resistance to cucurbit yellowing stunting disorder virus (CYSDV) in Cucumis melo L. HortScience 35:110-113.

Lopez-Sese, A.I., J. Staub, N. Katzir, and M.L. Gomez-Guillamon. 2002. Estimation of between and within accession variation in selected Spanish melon germplasm using RAPD and SSR markers to assess strategies for large collection evaluation. Euphytica 127:41-51.

Market, C.L. and I. Faulhaber. 1965. Lactate dehydrogenase isozyme patterns in fish. J. Expt. Zool. 159:319-332.

McCreight, J. D. 1998. Breeding melons for resistance to lettuce infectious 
yellows virus, p. 241-247. In: J.D. McCreight. (ed.). Cucurbitaceae '98: Evaluation and enhancement of cucurbit germplasm. ASHS Press, Alexandria, Va.

McCreight, J.D., G.W. Bohn, and T.W. Whitaker. 1987. PMR honeydew muskmelon. HortScience 22:177.

McCreight, J.D., A.N. Kishaba, and G.W. Bohn. 1984. AR Hale's Best Jumbo, AR 5, and AR Topmark, melon aphid-resistant muskmelon breeding lines. HortScience 19:309-310.

McCreight, J.D., H. Nerson, and R. Grumet. 1992. Melon (Cucumis melo L.), p. 267-294. In: G. Kalloo and B.O. Bergh (eds.). Improvement of vegetable crops. Pergamon Press, Oxford.

McCreight, J.D., J.E. Staub, N.M. Koppar, and U.C. Srivastava. 1993. Indo-U.S. Cucumis germplasm expedition. HortScience 28:492.

Mliki, A., J.E. Staub, Z.Y. Sun, and A. Ghorbel. 2001. Genetic diversity in melon (Cucumis melo L.): An evaluation of African germplasm. Genetic Resources and Crop Evolution 48:587-597.

Nei, M. 1973. Analysis of gene diversity in subdivided populations. Proc. Natl. Acad. Sci. USA 70:3321-3323.

Nei, M. 1978. Estimation of average heterozygosity and genetic distance from a small number of individuals. Genetics 89:583-590.

Neuhausen, S.L. 1992. Evaluation of restriction fragment length polymorphism in Cucumis melo. Theor. Appl. Genet. 83:379-384.

Pangalo, K.I. 1930. Critical review of basic literature on the systematics, geography and origin of cultivated and, partially wildly-growing melon (Kriticheskii obzor osnovnoi literatury po sistematike, geografii i proiskhozh dennyu kulturnykh i chast'yu dikkh dyni). Bul. Appl. Bot., Genet. Plant Breeding 23:397-442.

Pitrat, M., P. Hanelt, and K. Hammer. 2000. Some comments on infraspecific classification of cultivars of melon. Acta Hort. 510:29-36.

Richmond, R.C. 1972. Enzyme variability in the Drosophila williston group. 3. Amounts of variability in the superspecies D. paulistorum. Genetics 70:87-112.

Ridgway, G.J., S.W. Sherburne, and R.D. Lewis. 1970. Polymorphism in the esterases of Atlantic herring. Trans. Amer. Fish Soc. 99:147-151.

Robinson, R.W. and D.S. Decker-Walters. 1997. Cucurbits. CAB Intl., New York.

Rohlf, F.J. 1997. NTSYS-pc. Numerical taxonomy and multivariate analysis system. version 1.8 Exeter Software, New York.

Selander, R.K., M.H. Smith, S.Y. Yang, W.E. Johnson, and J.B. Gentry. 1971. Biochemical polymorphism and systematics in the genus Peromyseus. I. Variation in the old-field mouse (Peromyseus polionotus), p. 49-90. In: M.R. Marshall (ed.). Studies in genetics VI, Univ. of Texas Publication, Austin.

Shannon, C.E. and W. Weaver. 1949. The mathematical theory of communication. Univ. of Illinois Press, Urbana.

Shaw, C.R. and R. Prasad. 1970. Starch gel electrophoresis of enzymes:
A compilation of recipes. Biochemical Genet. 4:297-320.

Sokal, R.R. and P.H. Sneath. 1963. Biometry, 2nd ed. Freeman, San Francisco.

Spooner, D.M., R.G. van den Berg, W.L.A. Hetterscheid, and W.A. Brandenburg. 2003. Plant nomenclature and taxonomy: A horticultural and agronomic perspective. Hort. Rev. 28:1-60.

Staub, J. E. 2003. USDA vegetable crop research units - Cucumber and melon genetics (India-China data set), 5 May 2004. <http://www.hort. wisc.edu/usdavcru/staub/data/default.htm>.

Staub, J.E. and J.D. McCreight, 2004. Report of the Cucumis germplasm collection expedition in the state of Rajasthan, Madhya Pradesh and Uttar Pradesh, India, Oct.-Nov. 1992. 5 May 2004. <http://www.arsgrin.gov/npgs/cgclist.html\#Cucurbit>.

Staub, J.E., J. Box, V. Meglic, T.F. Horejsi, and J.D. McCreight. 1997. Comparison of isozyme and random amplified polymorphic DNA data for determining intraspecific variation in Cucumis. Genet. Resources Crop Evolution 44:257-269.

Staub, J.E., Y. Danin-Poleg, G. Fazio, T. Horejsi, N. Reis, and N. Katzir. 2000. Comparative analysis of cultivated melon groups (Cucumis melo L.) using random amplified polymorphic DNA and simple sequence repeat markers. Euphytica 115:225-241.

Staub, J.E., V. Meglic, and J.D. McCreight. 1998. Inheritance and linkage relationships of melon (Cucumis melo L.) isozymes. J. Amer. Soc. Hort. Sci. 123:264-272.

Stepansky, A., I. Kovalski, and R. Perl-Treves. 1999. Intraspecific classification of melons (Cucumis melo L.) in view of their phenotypic and molecular variation. Plant Systematics and Evolution 217:313-332.

Torres-Ruiz, R.A. and V. Hemleben. 1991. Use of ribosomal DNA spacer probes to distinguish cultivars of Cucurbita pepo L. and other Cucurbitaceae. Euphytica 53:11-17.

Wehner, T.C., J.D. McCreight, B.B. Rhodes, and X. Zhang. 1995. Expedition for cucurbit germplasm exchange with China. HortScience 30:890.

Whitaker, T.W. and W.P. Bemis. 1976. Cucurbits, Cucumis, Citrullus, Cucurbita, Lagenaria (Cucurbitaceae), p. 64-69. In: N.W. Simmonds (ed.). Evolution of crop plants. Longman, New York.

Whitaker, T.W. and G.N. Davis. 1962. Cucurbits: Botany, cultivation and utilization. Interscience Pub., New York.

Widrlechner, M.P., L.D. Knerr, J.E. Staub, and K.R. Reitsma. 1992. Biochemical evaluation of germplasm regeneration methods for cucumber, Cucumis sativus L. Plant Genet. Resources Nwsltr. 88/89:1-4.

Yeh, F.C., R.C. Yang, T. Boiley,Z.-H. Ye, and J.X. Mao. 1997. POPGENE, the user-friendly shareware for population genetic analysis. Mol. Biol. Biotechnol. Ctr. Univ. of Alberta, Edmonton, Alta., Canada.

Zentgraf, U., K. King, and V. Hemleben. 1992. Repetitive sequences are valuable as molecular markers in studies of phylogenetic relationships within the genus Cucumis. Acta Botanic-Neerlandica 41:397-406. 